\title{
Mental Toughness dan Competitive Anxiety pada Atlet Bola Voli
}

\author{
Panji Wahyu Algani', M. Salis Yuniardi ${ }^{2}$, Alifah Nabilah Masturah ${ }^{3}$ \\ 1,2,3Fakultas Psikologi, Universitas Muhammadiyah Malang \\ e-mail: ${ }^{1}$ panjiamazing@gmail.com, ${ }^{2}$ salis_ardi@yahoo.com, ${ }^{3}$ alifah_nabilah@umm.ac.id
}

\begin{abstract}
Abstrak. Competitive anxiety merupakan suatu hal negatif dalam menghadapi kompetisi karena dapat menurunkan capaian prestasi dan hal ini diindikasi salah satunya terkait dengan mental toughness atau kemampuan untuk bersikap positif ketika menghadapi suatu tekanan khususnya dalam sebuah pertandingan. Penelitian ini bertujuan untuk menguji hubungan antara mental toughness dengan competitive anxiety pada atlet bola voli. Terdapat 118 responden yang mengisi lengkap dan data selanjutanya dianalisis melalui product moment correlation Pearson SPSS 21.0. Hasil menunjukkan adanya hubungan negatif yang signifikan antara mental toughness dengan competitive anxiety $(r=-0,670$ dan $p<0,001)$. Semakin mampu seorang atlit untuk bersikap positif terhadap tekanan maka semakin rendah kecemasannya menghadapi kompetisi.
\end{abstract}

Kata kunci: mental toughness, competitive anxiety, atlet

Abstract. Competitive anxiety could distract concentration and eventually could decrease achievement. It has been indicated that competitive anxiety is related to mental toughness or an ability to develop a positive attitude in handling pressure particularly a competition. This study aimed to investigate the relationship between mental toughness and competitive anxiety. This study recruited 118 volleyball athletes and their data subsequently was analysed through product moment correlation Pearson SPSS 21.0. The result revealed that there was a significant negative correlation between mental toughness and competitive anxiety behavior $(r=-0,670$ and $p<0,001)$. More able to positively perceive pressure and handling the situation, athletes would be less anxiety in facing the competition.

Keyword: mental toughness, competitive anxiety, athletes

Bagi seorang atlet, pencapaian prestasi yang optimal tentunya menjadi tujuan utama selain kesehatan itu sendiri. Terdapat tiga faktor yang dapat mempengaruhi pencapaian prestasi yang optimal pada atlet yaitu faktor fisik, teknik, dan psikologis (Adisasmito, 2007). Aspek psikologis atau kepribadian yang menjadi dasar untuk meraih prestasi yang tinggi pada atlet dalam melakukan olahraga yaitu ambisi prestatif, kerja keras, gigih, mandiri, komitmen, cerdas, dan swakendali (Maksum, 2007), sedangkan pendapat lain mengatakan bahwa aspek psikologis yang sangat dominan dalam penampilan seorang atlet yaitu adalah motivasi, intelegensi, ketegangan atau kecemasan, dan program latihan mental (Utama, 1993). Sebaliknya, faktor psikologis yang biasanya menyebabkan prestasi atlet menurun, yaitu perasaan jenuh, tertekan, stress, ketakutan akan gagal, emosi yang meledak-ledak, kurangnya kepercayaan diri, kecemasan, dan lain sebagainya (Ravaie, 2006). 
Kecemasan merupakan salah satu dari sekian banyak persoalan yang dihadapi atlet, di mana kecemasan adalah reaksi emosi menghadapi situasi yang dipersepsikan mengancam dan tidak menyenangkan yang individu tersebut tidak mengetahui secara jelas sumbernya (Jamshidi, Hossien, Sajadi, Safari, \& Zare, 2011). Atlet tentunya memiliki tingkat kecemasan yang berbeda-beda tergantung dari kekhawatiran yang dialami oleh setiap atlet. Adapun beberapa faktor yang dapat mempengaruhi kecemasan atlet dalam olahraga terbagi menjadi dua yaitu faktor internal dan eksternal, di mana faktor internal meliputi kepercayaan diri, kecemasan bawaan, positive-negative-affect, sedangkan faktor eksternal meliputi pelatihan, skill level, cabang olahraga yang digeluti, situasi pertandingan, dan pengalaman bertanding (Ardini \& Jannah, 2017).

Competitive anxiety (kecemasan bertanding) merupakan salah satu tipe kecemasan yang dalam beberapa tahun terakhir telah dipertimbangkan di bidang psikologi khususnya psikologi olahraga. Competitive anxiety merupakan reaksi emosional negatif atlet ketika harga dirinya dirasa terancam, karena menganggap pertandingan sebagai tantangan yang berat, dan akan selalu megingat kemampuan penampilannya, yang berdampak pada perilaku bertanding (Smith, Smoll, \& Schutz, 1990). Competitive anxiety merupakan perasaan khawatir, gelisah, dan tidak tenang dengan mengaggap pertandingan sebagai sesuatu yang membahayakan (Martens et al, dalam Smith et al., 1990). Kecemasan bertanding ini biasanya akan menganggu penampilan atlet karena muncul perasaan takut untuk gagal atau menimbulkan beban moral jika tidak bisa menang (Miftah, 2017).

Permasalahan terkait kecemasan merupakan permasalahan psikologis yang terjadi pada atlet bola voli (Pradina \& Made, 2016). Negara Eutophia yang notabennya merupakan salah satu negara dengan olahraga bola voli terkuat juga menjadikan competitive anxiety sebagai suatu hal yang saat ini sedang menjadi perhatian dan menjadi bahan penelitian baru (Zenebe, Gebru, \& Techan, 2016). Hal ini juga dirasakan oleh pelatih Puryono dari salah satu klub bola voli terkenal di Pare yaitu Kelud Volly Ball Club, bahwa memang kecemasan seperti demam panggung, rasa was-was, khawatir, minder merupakan suatu perilaku yang sering dilakukan oleh setiap anak didiknya, di mana dari 30 atlet 20 diataranya pasti mengalami kecemasan dalam bertanding terlebih pada atlet-atlet muda yang baru saja menghadapi pertandingan (tournament) bergengsi, meskipun 3 sampai 4 kali pertandingan pun kecemasan bertanding pada atlet belum bisa dihilangkan secara total.

Di sisi lain, mental memiliki peranan yang sangat penting dalam pencapaian prestasi yang tinggi oleh atlet, yaitu $80 \%$ faktor kemenangan atlet profesional ditentukan oleh faktor mental (Adisasmito, 2007). Pendapat lain mengatakan bahwa 50\% dari hasil pertandingan ditentukan oleh faktor psikologis yaitu mental (Herman, 2011), di mana dapat diketahui apabila aspek fisik, teknik dan taktik sebaik apapun akan hancur jika aspek mental tidak pernah dilatih (Gunarsa, 2008). Oleh karena itulah, untuk mencapai penampilan yang optimal seorang atlet harus memiliki keseimbangan dalam kemampuan fisik dan kemampuan mental (Gucciardi, Gordon, \& Dimmock, 2008).

Salah satu bentuk mental yang dianggap penting harus dimiliki seorang atlit adalah mental toughness, atau kumpulan nilai-nilai, sikap, perilaku, dan emosi yang 
memungkinkan seseorang untuk mampu melestarikan dan mengatasi kendala, kesulitan, atau tekanan yang dialami, namun tetap menjaga konsentrasi dan motivasi agar konsisten dalam mencapai suatu tujuan (Gucciardi et al., 2008). Mental toughness dapat menjadikan seorang atlet untuk tetap merasa rileks, tenang, dan bersemangat, karena dapat mengembangkan dua keterampilan yaitu mengalirkan energi positif seperti berpersepsi menghilangkan kesulitan dan berfikir untuk bersikap atau menghiraukan masalah, tekanan, kesalahan, dan persaingan dalam suatu pertandingan (Jones, 2010). Selain itu, mental toughness merupakan ketetapan hati pada tingkat tinggi, menolak ditekan namun harus mampu untuk tetap fokus pada situasi menekan, serta kapasitas untuk bertahan di sepanjang pertandingan (Cashmore, 2008). Mental toughness merupakan kumpulan atribut psikologis atlet yang unggul yang dapat dilihat pada saat melakukan latihan atau pertandingan (Jones, 2010). Mental toughness pada atlet akan memperlihatkan kegigihan yang luar biasa meski secara objektif tidak ada harapan untuk memenangkan suatu pertandingan (Gunarsa, 2008).

Berdasarkan uraian di atas, maka diasumsikan adanya hubungan negatif antara mental toughness dengan competitive anxiety. Hal tersebut juga diperkuat dengan dimensi dari mental toughness yang cenderung thrive though challege atau mampu menghadapi tantangan, sport awareness atau mampu bekerja dalam tim, though attitude atau mampu menghadapi tekanan, desire success atau selalu berfikir optimis untuk mencapai keberhasilan (Gucciardi, Gordon, \& Dimmock, 2009). Di mana terlihat sekali dari dimensi-dimensi tersebut berbanding terbalik dengan atribut competitive anxiety seperti kecemasan kognitif, kecemasan afektif, kecemasan motorik dan kecemasan somatik yang cenderung selalu berprasangka khawatir, ketakutan akan gagal, jantung berdebar-debar, gelisah, tegang, dan sembrono dalam menghadapi sebuah tekanan atau tantangan (Smith, Smoll, \& Schutz, 1990). Selain itu, untuk memperkuat kedua variabel penelitian psikologi antara keduaya, terdapat suatu hal yang sama yaitu competitive (kompetisi) pada mental toughness tepatnya dalam dimensi thrive though challenge yaitu competitivenes atau kompetisi yang cenderung positif dalam melakukan pertandingan (Gucciardi et al., 2009).

Dengan demikian tujuan dari penelitian ini adalah untuk mengetahui hubungan antara mental toughness dengan competitive anxiety pada atlet bola voli. Manfaat penelitian ini secara teoritis diharapkan dapat menambah pengetahuan dalam bidang psikologi olahraga, sekaligus secara praktis diharapkan dapat memberikan informasi bagi atlet maupun para pelatih khususnya mengenai aspek-aspek terkait mental toughness dan competitive anxiety.

\section{METODE PENELITIAN}

Penelitian ini menggunakan metode penelitian kuantitatif dengan jenis korelasional yang bertujuan untuk mengetahui korelasi (hubungan) antara kedua variabel, dan merupakan penelitian tradisional yang sudah cukup lama digunakan, serta sudah memenuhi kaidahkaidah ilmiah yang bersifat kongkrit, obyektif, terukur, rasional, sitematik, serta menggunakan angka-angka dan menggunakan analisis statistik (Sugiyono, 2011). 
Pegambilan sampel dilakukan pada dua buah klub bola voli di Kediri, Jawa Timur. Berdasarkan klasifikasi tersebut didapatkan bahwa partisipan yang digunakan dalam penelitian ini sebanyak 118 atlet, di mana sebanyak 50 (42\%) subjek adalah atlet laki-laki dan sebanyak 63 (58\%) subjek adalah atlet perempuan, dengan kategori usia 12-17 tahun sebanyak 99 (84\%) atlet masuk dan kategori usia 18-22 tahun sebanyak 19 (16\%), di mana keseluruhan subjek masuk dalam kategori usia remaja.

Variabel bebas (X) dalam penelitian ini adalah mental toughness. Mental toughness (ketangguhan mental) merupakan sikap atau penilaian diri seseorang khususnya atlet untuk mengatasi kendala, kesulitan, bahkan tekanan, agar tetap menjaga konsentrasi dan motivasi yang merupakan ketetapan hati dari energi positif untuk mencapai suatu tujuan dalam bertahan disepanjang pertandingan. Skala mental toughness disusun berdasarkan dimensi thrive though challenge, sport awareness, tough attitude, dan desire succes (Gucciardi et al., 2009). Hasil uji koefisien validitas item mental toughness berkisar antara 0,306 - 0,706. Realibilitas skala mental toughness 0,925 .

Variabel terikatnya (Y) yaitu competitive anxiety. Competitive anxiety (kecemasan bertanding) merupakan suatu perilaku atau tindakan seseorang khususnya atlet terhadap reaksi emosi negatif, seperti, gelisah, khawatir, tidak tenang, tegang, bahkan takut ketika harga dirinya terancam yang menganggap pertandingan sebagai sesuatu yang membahayakan sehingga mengakibatkan kekalahan. Skala competitive anxiety (kecemasan bertanding) disusun berdasarkan aspek cognitive, motoric, afektive, dan somatic, dari Sport Anxiety Scale (SAS) Smith et al., 1990 (Amir, 2012). Hasil uji koefisien validitas item competitive anxiety berkisar antara 0,356 - 0,761. Realibilitas skala competitive Anxiety 0,897.

\section{HASIL PENELITIAN}

Hasil screening awal menunjukkan tidak adanya missing data. Selanjutnya nilai skewness $=-0,028$ dan nilai kurtosis $=-0,119$ menunjukkan bahwa distribusi data adalah normal karena berada diantara \pm 1 . Grafik $Q-Q$ Plot yang menyatakan data linier.

Tabel 1.

Perhitungan Kategori Mental Toughness dan Competitive Anxiety

\begin{tabular}{lccccrr}
\hline Variabel & Mean & $\begin{array}{l}\text { Standart } \\
\text { Deviasi }\end{array}$ & Kategori & Interval & Frekuensi & Presentase \\
\hline Mental & 62,5 & 5,51 & Tinggi & $69-82$ & 31 & $26 \%$ \\
Toughness & & & Sedang & $62-68$ & 60 & $51 \%$ \\
& & & Rendah & $49-61$ & 27 & $23 \%$ \\
Competitive & \multirow{2}{*}{39,7} & 7,43 & Tinggi & $44-62$ & 49 & $41 \%$ \\
Anxiety & & & Sedang & $35-43$ & 29 & $24 \%$ \\
& & & Rendah & $17-34$ & 41 & $35 \%$ \\
\hline
\end{tabular}


Tabel 1 menunjukkan data kategori variabel mental toughness dengan nilai mean sebesar 62,5 dan standart deviasi sebesar 5,51. Untuk variabel mental toughness kategori tinggi sebanyak 26\% yaitu 31 subjek dan untuk kategori rendah dengan presentase sebanyak 23\% yaitu 27 subjek. Data kategori variabel competitive anxiety dengan nilai mean sebesar 39,7 dan standart deviasi sebesar 7,43. Untuk variabel competitive anxiety kategori tinggi sebanyak $41 \%$ yaitu 49 subjek dan untuk kategori rendah dengan presentase sebanyak 35\% yaitu 41 subjek.

Berdasarkan analisa data yang telah dilakukan dengan menggunakan analisa product moment Pearson, diperoleh koefisien $(r)$ sebesar -0,670 dengan nilai signifikansi $(p)$ sebesar $0,000<0,05$. Hal ini menunjukkan bahwa terdapat hubungan negatif antara mental toughness dengan competitive anxiety. Semakin tinggi mental toughness yang dimiliki oleh atlet bola voli maka semakin rendah competitive anxiety yang dilakukan, sebaliknya semakin rendah mental toughness yang dimiliki oleh atlet bola voli maka semakin tinggi competitive anxiety yang dilakukan. Dari hasil penelitian didapatkan koefisien determinasi variabel $\left(\mathrm{r}^{2}\right)$ sebesar $0,45(45 \%)$. Adapun sumbangan antara mental toughness dengan competitive anxiety sebesar $45 \%$ dan sisanya 55\% ditentukan oleh variabel lain.

\section{DISKUSI}

Penelitian ini dilakukan untuk mengetahui bagaimana hubungan antara mental toughness dengan competitive anxiety pada atlet bola voli di Pare Kediri Jawa Timur. Hasil analisa data menunjukkan semakin positif seorang atlit bola voli melihat arti dari tekanan dan mampu mengambil tindakan-tindakan untuk mengatasinya maka semakin berkurang kecemasannya menghadapi sebuah kompetisi. Hal ini menunjukkan bahwa hipotesa yang diajukan dalam penelitian ini diterima.

Hal ini sesuai dengan dugaan awal peneliti terkait kedua variabel bahwa competitive anxiety yang merupakan reaksi negatif, seperti gelisah, khawatir, tidak tenang, tegang, bahkan takut kalah dalam suatu pertandingan, berbanding terbalik dengan mental toughness yang cenderung memunculkan reaksi positif dalam mengatasi kendala, kesulitan, tekanan pada seseorang khususnya atlet dalam melakukan suatu pertandingan (Smith et al., 1990). Selain itu diperkuat dengan dimensi thrive though challege pada mental toughness yang memiliki atribut competitivenes atau kompetisi yang cenderung positif ketika menghadapi tekanan atau dapat dikatakan tidak mengalami kecemasan (anxiety) saat sedang bertanding (Gucciardi et al., 2009).

Berdasarkan pernyataan di atas, diketahui bahwa dari 118 atlet bola voli memiliki nilai rata-rata mental toughness yang lebih tinggi yaitu 62,5 dibandingkan dengan competitive anxiety yang hanya sekitar 39,7. Hal tersebut sejalan dengan penelitian sebelumnya yang menyatakan bahwa atlet dengan kategori olahraga beregu memiliki tingkat kecemasan bertanding yang lebih rendah dibandingkan ketangguhan mental yang dimiliki, karena dalam penelitian sebelumnya dinyatakan pula bahwa atlet dengan kategori olahraga individu body contact atau kontak langsung, seperti olahraga bela diri pencak silat menunjukkan tingkat kecemasan bertanding lebih tinggi yang mengakibatkan 
ketangguhan mentalnya cenderung rendah (Raynaldi et al., 2016). Namun dalam penelitian ini rata-rata mental toughness responden lebih banyak masuk dalam kategori sedang yaitu sebanyak 60 atlet, sedangkan competitive anxiety responden lebih banyak masuk dalam kategori tinggi yaitu sebanyak 49 atlet, artinya dalam penelitian ini mental toughness atlet mayoritas masuk dalam kategori sedang atau cenderung mentalnya masih belum stabil dan competitive anxiety mayoritas masuk dalam kategori tinggi atau banyak subjek merasa masih cukup cemas dalam bertanding.

Ada beberapa faktor yang mempengaruhi penelitian ini, salah satunya dikarenakan memang kebanyakan responden merupakan kategori remaja, yaitu $84 \%$ atau 99 atlet masuk dalam usia 12-17 tahun dan sisanya 16\% atau 19 atlet masuk dalam usia 18-22 tahun. Hal ini menyatakan bahwa atlet remaja tergolong atlet yang masih kurang dalam hal pengalaman dan keterampilan yang tidak jarang mengalami suatu kecemasan dalam suatu pertandingan, seperti munculnya pikiran-pikiran negatif, stressor tinggi, sehingga terkadang reaksi mental pada atlet cenderung menurun atau berubah-ubah (Jatmika, 2016). Hal tersebut diperkuat dengan teori mengenai remaja yang cenderung memiliki sikap dan perilaku sembrono, suka mencoba hal baru, takut salah, tidak percaya diri, sesuai dengan pernyataan yang menyatakan bahwa usia remaja merupakan usia transisi dari masa kanak-kanak menuju masa dewasa awal yang tidak jarang sering memunculkan emosi negatif dalam bersikap dan berprilaku (Santrock, 2012).

Pada penelitian ini didukung pula dengan penelitian-penelitian sebelumnya, salah satunya adalah penelitian yang digunakan untuk meningkatkan mental toughness dan mengurangi competitive anxiety adalah dengan memberikan pelatihan pengolahan kecemasan yang pastinya untuk mengurangi tingkat kecemasan pada atlet dengan menggunakan teknik relaksasi atau melakukan relaksasi terhadap otot-otot tubuh, selain itu juga dapat menggunakan teknik imagery untuk membantu relaksasi dan tingkat kefokusan pada atlet di mana psikolog mendesain langsung situasi dan kondisi atlet dalam keadaan nyata ketika bertanding, seperti menempel foto-foto lawan atau gambar-gambar stadion (Jatmika, 2016), atau melakukan pelatihan guna meningkatkan self-belief atas kemampuan fisik dan mental pada atlet khususnya atlet bola voli. Hal tersebut sesuai dengan penelitian yang menyatakan bahwa keyakinan diri (self belief) atau kepercayaan diri merupakan salah satu aspek kepribadian yang peting untuk melakukan aktualisasi potensi yang dimilki individu (Rachmawati et al., 2014). Artinya bahwa terdapat berbagai macam cara yang digunakan untuk meningkatkan mental toughness yang cenderung lebih masuk dalam kategori sedang dan competitive anxiety yang lebih banyak masuk dalam kategori tinggi pada penelitian ini, salah satunya dengan memberikan pelatihan relaksasi, imegery, meningkatkan kepercayaan diri dan berbagai macam teknik lainnya.

Pada penelitian ini diketahui bahwa permasalahan terkait competitive anxiety memang sering terjadi pada kehidupan seorang atlet, tidak hanya atlet bola voli tetapi juga atletatlet dengan kategori olahraga lain yang dapat mengurangi mental toughness pada saat bertanding. Padahal dalam suatu pertandingan faktor psikologis sangat berperan dalam mencapai sebuah kemenangan atlet, di mana $80 \%$ faktor kemenangan atlet adalah faktor mental yaitu mental toughness (Adisasmito, 2007). Berdasarkan uraian tersebut, secara keseluruhan subjek dalam penelitian ini sudah menunjukkan sikap dan perilaku yang cukup baik, terlihat dari jumlah rata-rata subjek yang masih memasuki kategori usia 
remaja namun sudah dapat menunjukkan mental toughness yang cenderung tidak buruk tetapi juga tidak baik atau masuk dalam kategori sedang. Sikap tersebut minimal harus tetap dipertahankan atau dapat lebih ditingkatkan kembali, karena dalam penelitian ini diketahui sumbangan mental toughness terhadap competitive anxiety adalah sebesar $45 \%$ atau dengan kata lain sisanya 55\% ditentukan oleh variabel lain. Salah satu variabel yang dapat meningkatkan mental toughness dan mengurangi competitive anxiety yaitu variabel self confident (Forastero, 2016).

Terlepas dari hal tersebut, topik penelitian ini masih relatif baru khususnya di Indonesia sehingga hasil penelitian ini bernilai bagi perkembangan pengetahuan terkait psikologi olahraga sekaligus bermanfaat secara praktis bagi para atlet maupun pelatih olahraga. Namun penelitian ini tidak dapat memprediksi sebab-akibat dikarenakan penelitian ini hanya berfokus untuk mengetahui hubungan selain subyek yang dilibatkan juga dalam kategori tertentu sehingga perlu replikasi pada kelompok subyek yang lebih luas apabila hendak berbicara mengenai generalisasi hasil.

\section{SIMPULAN DAN IMPLIKASI}

Berdasarkan hasil penelitian yang dilakukan dapat disimpulkan bahwa hipotesis diterima atau terdapat hubungan antara mental toughness dengan competitive anxiety. Semakin tinggi mental toughness yang dimiliki oleh atlet bola voli maka semakin rendah competitive anxiety yang dilakukan, sebaliknya semakin rendah mental toughness yang dimiliki atlet bola voli maka semakin tinggi competitive anxiety yang dilakukan. Selanjutnya replikasi penelitian pada kelompok subyek yang lebih luas atau bahkan menguji kausalitas baik dengan penelitian longitudinal maupun eksperimen sangat disarankan.

\section{REFERENSI}

Adisasmito, L. (2007). Mental Juara Modal Atlet Berprestasi. Jakarta: Raja Grafindo Persada.

Amir, N. (2012). Pengembangan Alat Ukur Kecemasan Olahraga. Jurnal Penelitian Dan Evaluasi Pendidikan, 16(1).

Ardini, F., \& Jannah, M. (2017). Pengaruh Pelatihan Teknik Relaksasi Pernafasan Dalam Terhadap Competitive State Anxiety Pada Atlet UKM Bulu Tangkis Universitas Negeri Surabaya. Jurnal Psikologi Pendidikan, 4(2), 1-5.

Cashmore, E. (2008). Sport and Exercise Psychology: The Key Concepts, Second Edition (Second Edi). London and New York: Routledge Taylor and Francis Group.

Forastero, A. (2016). Mental Toughness dan Competitive Anxiety Pada Atlet Futsal. Universitas Surabaya.

Gucciardi, D. F., Gordon, S., \& Dimmock, J. A. (2008). Towards an Understanding of 
Mental Toughness in Australian Football. Journal Of Applied Sport Psychology, 20, 261-281. https://doi.org/10.1080/10413200801998556

Gucciardi, D. F., Gordon, S., \& Dimmock, J. A. (2009). Development and preliminary validation of a mental toughness inventory for Australian football. Psychology of Sport and Exercise, 10(1), 201-209. https://doi.org/10.1016/j.psychsport.2008.07.011

Gunarsa, S. D. (2008). Psikologi Olahraga Prestasi. Jakarta: Gunung Mulia. Jakarta: Gunung Mulia.

Herman. (2011). Psikologi Olahraga. ILARA, 2(2), 1-7.

Jamshidi, A., Hossien, T., Sajadi, S. S., Safari, K., \& Zare, G. (2011). The relationship between sport orientation and competitive anxiety in elite athletes. Procedia - Social and Behavioral Sciences, 30, 1161-1165. https://doi.org/10.1016/j.sbspro.2011.10.226

Jatmika, D. (2016). Efektivitas Pelatihan Pengelolaan Kecemasan Terhadap Kecemasan Berkompetisi Pada Atlet Bulu Tangkis Remaja. Jurnal Psikologi Psibernetika, 9(2).

Jones, G. (2010). Journal of Applied Sport Psychology What Is This Thing Called Mental Toughness? An Investigation of Elite Sport Performers What Is This Thing Called Mental Toughness? An Investigation of Elite Sport Performers. Journal of Applied Sport Psychology, 14(3), 205-218. https://doi.org/10.1080/10413200290103509.

Maksum, A. (2007). Kualitas Pribadi Atlet: Kunci Keberhasilan Meraih Prestasi Tinggi. Anima, Indonesian Psychological Journal, 22(2), 108-115.

Miftah, F. (2017). Pengaruh Kecemasan Bertanding Terhadap Peak Performance Pada Atlet Sofball Universitas Negeri Yogyakarta. Bimbingan Dan Konseling Edisi 1, 71-79.

Pradina, Y. W., \& Made, P. (2016). Tingkat Kecemasan Atlet Bola Voli Putri Pada Kejuaraan Liga Remaja Tingkat Jawa Timur Tahun 2016. Kesehatan Olahraga, $6(2)$.

Rachmawati, L. P., Karini, S. M., \& Priyatama, A. N. (2014). Hubungan antara kepercayaan diri dengan kecemasan menghadapi pertandingan pada atlet karate unit kegiatan mahasiswa institut karate-do indonesia universitas Ssebelas maret (ukm inkai uns). Candrajiwa, 4, 245-258.

Ravaie, Y. R. F. (2006). Hubugan Kecerdasan Emosi Dengan Kecemasan Menghadapi Pertandingan Olah Raga. Yogyakarta: Universitas Islam Indonesia.

Raynaldi, F. B., Rachmah, D. N., \& Akbar, S. N. (2016). Hubungan Ketangguhan Mental Dengan Kecemasan Bertanding Pada Atlet Pencak Silat Di Banjarbaru Relationship Between Mental Toughness and Competitive Anxiety in Pencak Silat Di Banjarbaru. Jurna Ecopsy, 3(3), 149-154. 
Santrock, J. W. (2012). Life Span Development: Perkembangan Masa Hidup. (A. Chusairi, J. Damanik, H. Sinaga, \& Y. Sumiharti, Eds.) (Edisi 13 J). Jakarta: Erlangga.

Smith, R. E., Smoll, F. L., \& Schutz, R. W. (1990). Measurement and correlates of sportspecific cognitive and somatic trait anxiety: The sport anxiety scale. Anxiety Research, 2(4), 263-280. https://doi.org/10.1080/08917779008248733.

Sugiyono. (2011). Metode Penelitian Kuantitatif, Kualitatif, dan $R$ \& D. Bandung: Alfabeta.

Utama, B. A. (1993). Aspek Psikologis Dalam Pembinaan Atlet Tenis Meja. Fakultas Ilmu Keolahragaan UNY, 1-8.

Zenebe, M. D., Gebru, T. H., \& Techan, Z. (2016). Relationship between competitive anxiety , confidence and performance among female volleyball players. International Journal of Physical Education, Sport and Health, 3(5), 337-342. 